\title{
Growth Regulators Affect the Growth and Biochemical Activity of Curcuma longa Plants Grown in vitro
}

\author{
Meire Pereira de Souza Ferrari ${ }^{1}$, Mayara dos Santos Queiroz ${ }^{2}$, Matheus Marquezini de Andrade ${ }^{2}$, \\ Jessica Rezende Trettel $^{1} \&$ Hélida Mara Magalhães ${ }^{3}$ \\ ${ }^{1}$ Student Postgraduate Programs in Biotechnology Applied to Agriculture, Paranaense University, Umuarama, \\ Paraná, Brazil \\ ${ }^{2}$ Agronomist, Paranaense University, Umuarama, Paraná, Brazil \\ ${ }^{3}$ Postgraduate Programs in Biotechnology Applied to Agriculture, Paranaense University, Umuarama, Paraná, \\ Brazil \\ Correspondence: Hélida Magalhães, Paranaense University, Mascarenhas de Moraes Square, 4282, 87502-210 \\ Umuarama, Paraná, Brazil. Tel: 55-443-621-2830. E-mail: helidamara@prof.unipar.br
}

Received: April 8, 2019 Accepted: May 20, $2019 \quad$ Online Published: July 15, 2019

doi:10.5539/jas.v11n10p277 URL: https://doi.org/10.5539/jas.v11n10p277

The research is financed by CAPES and UNIPAR.

\begin{abstract}
This study aimed to evaluate the in vitro growth and biochemical activity of Curcuma longa explants using different MS medium formulations and growth regulators. In all the experiments, plants were grown in MS medium supplemented with agar $\left(6.5 \mathrm{~g} \mathrm{~L}^{-1}\right)$ and $\mathrm{pH}$ adjusted to 5.8. In the first assay, the MS culture medium at $70 \%$ strength, supplemented with $30 \mathrm{~g} \mathrm{~L}^{-1}$ of sucrose, and without the addition of activated carbon, resulted in the highest number of shoots. The sucrose concentration of $60 \mathrm{~g} \mathrm{~L}^{-1}$, combined with the addition of actived charcoalin half-strength MS medium, resulted in the increased root dry mass, root collar diameter, and relative chlorophyll index. In the second assay, the highest root collar diameter and dry matter of shoots and roots were found in the MS medium supplemented with 4.44 BAP, $0.46 \mathrm{KIN}$, and 1.08 NAA. The MS medium with 8.88 BAP, $0.92 \mathrm{KIN}$, and $2.16 \mu \mathrm{M}$ NAA resulted in the highest number of shoots (7.75), number of leaves (35), and shoot length $(88.57 \mathrm{~mm})$. The antioxidant activity was significantly higher in the treatments that resulted in better plantlets growth performance, demonstrating that the antioxidant activity is related to other factors such as a possible role of growth regulators on the elicitation of compounds in plants. Superoxide dismutase had a high enzymatic activity in both assays, whereas the enzymatic activity of catalase and ascorbate peroxidase was dependent on the culture media used.
\end{abstract}

Keywords: antioxidant activity, enzymes, growth regulators, micropropagation, Zingiberaceae

\section{Introduction}

Curcuma longa belongs to family Zingiberaceae and is a perennial herbaceous plant that has a rhizome with high nutrient contents and secondary metabolism compounds (Raina et al., 2005). From the rhizome, an orange-yellow-colored oil, composed mainly of curcuminoids and various volatile compounds such as monoterpenes and sesquiterpenes, can be extracted (Raina et al., 2005). The main active constituent of $C$. longa is curcumin, which is widely used in medicines owing to its anti-inflammatory and antitumor activity (Chen et al., 2011; Zhao et al., 2017) and antioxidant and antimicrobial properties (Péret-Almeida, 2005).

Despite the numerous benefits of $C$. longa to human health, there is little information available on the cultivation techniques of this species. For the production of $C$. longa plantlets, the most widely used method is vegetative propagation through the multiplication of rhizomes (Faridah et al., 2011). However, this practice has some limitations, especially because the rhizomes are used for the commercialization and extraction of essential oils. In addition, the rhizomes are also used in the preparation of dyes and other food products. Therefore, the $C$. longa cultivators are obligated to allocate a part of the total rhizome yield for planting in new cultivation areas. Another limiting factor is that rhizomes may be contaminated by pathogenic fungi (Ramakrishnan \& Sowmini, 
1955). This shows that the conventional multiplication capacity of $C$. longa is very limited compared to other propagation methods (Miachir et al., 2004).

Thus, micropropagation of ginger plants has been used with the purpose of replacing the conventional system of obtaining plantlets. The use of this technique guarantees a greater multiplication of plants in a short time in a pathogen=free manner (Ramakrishnan \& Sowmini, 1955). Another advantage of in vitro cultivation is the possibility of controlling important factors such as flowering time, plant size, and vigor, as well as rhizome dormancy problems (Girardi et al., 2007).

The culture medium is the primary factor to be determined during the establishment of a micropropagation protocol (George et al., 2008). The culture medium consists of several compounds and nutrients that are added in specific amounts to meet the requirements and ensure the growth and development of a plant (Grout, 2017). Of these compounds, growth regulators, nutrients, carbohydrates, and antioxidants play a prominent role in plant growth and development (George et al., 2008). When the composition and balance of nutrients and plant hormones in the culture medium is not adequate, the plantlets formation is inhibited, resulting in increased production costs and delay in plantlets formation (Grout, 2017).

Among the growth regulators, cytokinins and auxins are the most frequently used plant hormones in the in vitro culture medium, both of which may influence both plant morphology and physiological responses, as reported by Antoniazzi et al. (2016). These authors showed, during their trials with C. longa, that the addition of auxins and cytokinins to the Murashige and Skoog (MS) medium increases the shoot fresh mass, as well as the number and dry mass of the roots. Sucrose is the most widely used carbon source in the majority of micropropagation protocols (Aros et al., 2017; Rodrigues et al., 2017). It modulates the formation of carbon chains, as plants at this growth stage have a negligible photosynthetic rate (George et al., 2008). In turn, the actived charcoalacts in the culture medium as an antioxidant, inhibiting the oxidation of compounds such as phenolics (Thomas, 2008).

To date, the studies on this topic have reported only the isolated effects of different compounds used in the culture media, for establishing the micropropagation protocols for $C$. longa. However, it is important that these compounds are tested in different combinations, as the plant responses may change due to the synergistic and antagonistic interactions of different compounds in the culture medium or by the interaction of the medium with the explant (George et al., 2008; Grout, 2017). Another little-understood aspect is how the composition of the culture medium affects the metabolism of the plantlets. When the explant is placed in contact with the culture medium, a series of biochemical reactions begin to occur in the plant. This study was focused on defense reactions, especially against oxidative damages that limit explant growth.

Among the substances that cause oxidative damage in plants, free radicals such as reactive oxygen species (ROS) and reactive nitrogen species (RNS) are the most important ones (Noctor et al., 2018), causing extensive damage to lipids, nucleic acids, and proteins (Gill \& Tuteja, 2010). Through their history of evolution via natural selection, plants have developed various defenses against oxidative damages (Noctor et al., 2018). The main substances responsible for this defense mechanism are a series of enzymes, including superoxide dismutase (SOD), catalase (CAT), and ascorbate peroxidase (APX) (Gill \& Tuteja, 2010), and compounds of secondary metabolism, belonging to the groups of terpenoids and phenolic compounds (Matkowski, 2008; Silva et al., 2010) and vitamins C and E (Sies \& Stahl, 1995).

For the propagation of $C$. longa, information on how the culture medium composition can affect the biochemical activity of the antioxidant defense mechanism is still limited. Thus, as a first hypothesis, it is expected that: (1) plants that show limited growth according to the culture medium tend to increase the activity of all substances that have an antioxidant effect. Alternatively, a second hypothesis is: (2) plants exposed to a particular culture medium could have high antioxidant activity despite showing optimum growth in that culture medium. This could indicate that another antioxidant defense mechanism, which was not tested, is acting and contributing to promoting the explant growth, or that the culture medium compounds are acting as an elicitor (Abraham et al., 2011; Victório et al., 2011). In addition, the growth and mineral nutrition of plantlets is likely compromised during growth in a less-than-optimal culture medium (George et al., 2008).

Therefore, it is important to establish the optimal conditions for cultivation, taking into account the characteristic features of each species. Thus, to expand our knowledge in this area, and to provide technical expertise to the $C$. longa producers, it is necessary to establish a protocol for the use of compounds in the in vitro culture medium. This is because these compounds directly modulate the plant development, which can cause an increase in the characteristics desirable for the in vitro cultivation of $C$. longa, or even its death, if the quantities used exceed the maximum values tolerable by the species under study. Thus, this study aimed to evaluate the in vitro growth and biochemical activity of Curcuma longa explants using different MS medium formulations and growth regulators. 


\section{Material and Methods}

\subsection{Plant Material}

Rhizomes of C. longa were collected from the garden of medicinal plants of the Unversity Paranaense (UNIPAR) in Umuarama, Paraná State, Brazil. The rhizomes were used as explants for the initiation of the in vitro culture. Explants with $15 \mathrm{~mm}( \pm 3 \mathrm{~mm})$ length were surface sterilized by immersion in $2 \%(\mathrm{v} / \mathrm{v})$ sodium hypochlorite solution for $20 \mathrm{~min}$, followed by three washes using sterile distilled water, and then used in the assays.

\subsection{First Assay-Different Compositions of MS Medium}

The first assay was used to measure the effects of the interaction among different concentrations of the MS medium (Murashige \& Skoog, 1962), sucrose, growth regulators, and the addition or non-addition of activated charcoal, on the in vitro growth of $C$. longa. The assay had a completely randomized design (CRD) with five treatments (culture medium) and five replicates of four glass vials, twenty explants were used for each treatment.

The different tested compositions of the culture media are shown in Table 1. All the culture media were supplemented with $6.5 \mathrm{~g} \mathrm{~L}^{-1}$ of agar (Kasvi ${ }^{\mathbb{B}}$ ), and the $\mathrm{pH}$ was standardized to 5.8 (Antoniazzi et al., 2016; Ferrari et al., 2016).

Table 1. Different compositions of the Murashige and Skoog medium for in vitro growth of Curcuma longa explants

\begin{tabular}{llllll}
\hline Medium Constituents & Treatment M1 & Treatment M2 & Treatment M3 & Treatment M4 & Treatment M5 \\
\hline MS medium & $100 \%$ & $50 \%$ & $50 \%$ & $70 \%$ & $70 \%$ \\
Sucrose $\left(\mathrm{g} \mathrm{L}^{-1}\right)$ & 30 & 30 & 60 & 30 & 60 \\
Activated charcoal $\left(\mathrm{g} \mathrm{L}^{-1}\right)$ & absent & absent & 4.5 & absent & 4.5 \\
BAP $(\mu \mathrm{M})$ & absent & 8.88 & 8.88 & 8.88 & 8.88 \\
NAA $(\mu \mathrm{M})$ & absent & 2.16 & 2.16 & 2.16 & 2.16 \\
KIN $(\mu \mathrm{M})$ & absent & 0.92 & 0.92 & 0.92 & 0.92 \\
\hline
\end{tabular}

\subsection{Second Assay-Effect of Different Concentrations of Auxins and Cytokinins}

The use of 6-benzylaminopurine (BAP) and kinetin (KIN) along with $\alpha$-naphthaleneacetic acid (NAA) was tested in this in vitro assay. Concentrations of the growth regulators were established based on the results of Antoniazzi et al. (2016). The sterilized explants were inoculated into 350-mL transparent glass vials, containing MS culture medium supplemented with $30 \mathrm{~g} \mathrm{~L}^{-1}$ of sucrose, $6.5 \mathrm{~g} \mathrm{~L}^{-1}$ of agar (Kasvi ${ }^{\circledR}$ ), and $\mathrm{pH}$ adjusted to 5.8. The composition of the culture media used in this assay is presented in Table 2. The assay used a completely randomized design with five treatments and five replicates of four glass vials. Twenty explants were used for each treatment.

Table 2. Different concentrations of auxins and cytokinins added to the Murashige and Skoog medium for in vitro growth of $C$. longa explants

\begin{tabular}{llll}
\hline Growth regulators & & & \\
\hline Treatments & BAP $(\mu \mathrm{M})$ & KIN $(\mu \mathrm{M})$ & NAA $(\mu \mathrm{M})$ \\
\hline T1 & 0.0 & 0.0 & 0.0 \\
T2 & 4.44 & 0.46 & 1.08 \\
T3 & 8.88 & 0.92 & 2.16 \\
T4 & 13.32 & 0.0 & 3.24 \\
T5 & 17.76 & 1.38 & 7.20 \\
\hline
\end{tabular}

\subsection{Growth Conditions and Measurements}

In both assays, the glass vials containing the inoculated explants were kept in a culture room at $25{ }^{\circ} \mathrm{C}\left( \pm 2{ }^{\circ} \mathrm{C}\right)$ under $24 \mathrm{~h}$ of light for 90 days. All treatments were maintained at a luminous intensity of 2000 Lux from white light emitter diode (LED) lamps, Blumenau, model LED T8 [10W 6,000K, 100-240 Volts, 50-60 Hertz, and potency factor $\geq 0.92$ (High potency factor)]. 
In both the assays, the following morphological characteristics were measured: number of shoots (NS), number of roots (NR), number of leaves (NL), relative chlorophyll index (RCI), shoot length (SL), root collar diameter (CD), shoot dry mass (SDM), and root dry mass (RDM). The shoot length and root collar diameter were measured using a digital caliper with an accuracy of $0.01 \mathrm{~mm}$. The relative chlorophyll index was measured using a chlorophyll meter clorofiLOG® ${ }^{\circledR}$, model CFL-1030 (Falker Automação Agrícola Ltda., Porto Alegre, RS, BRA), for different turmeric leaves collected randomly from the glass vials. The number of roots was measured by counting the primary and lateral roots, excluding rootlets and root hairs. For the determination of shoot and root dry mass, the plantlets were separated into shoots and roots, dried in an oven at $65{ }^{\circ} \mathrm{C}$ for four days, and then weighed.

\subsection{Measurement of Nutrient Concentration}

The concentrations of nitrogen $(\mathrm{N})$, potassium $(\mathrm{K})$, calcium $(\mathrm{Ca})$, copper $(\mathrm{Cu})$, and zinc $(\mathrm{Zn})$ in the $C$. longa shoots were measured in the two in vitro assays. Dried samples of the C. longa shoots were used (Malavolta et al., 1980). The accuracy of the different methods was verified by analyzing the standard reference material.

\subsection{Measurement of Antioxidant Activity by the DPPH Method}

The extracts were prepared using $1.0 \mathrm{~g}$ of fresh leaves and the methodology proposed by Magalhães et al. (2017). Free radical scavenging activity of different extracts of $C$. longa shoots were measured using 2,2-diphenyl-1-picrylhydrazyl (DPPH) (Rufino et al., 2009). The results were expressed as the percentage of free radical scavenging activity (\%FRS), according to the equation:

$$
a a=\left[\left(A_{\text {control }}-A_{\text {test }}\right) / A_{\text {control }}\right] \times 100
$$

where, $a a$ is the antioxidant activity (\%) $A_{\text {control }}$ is the absorbance of the control solution without the extracts, and $A_{\text {test }}$ is the absorbance of different extracts.

\subsection{Measurement of Enzyme Activity}

The enzymatic extract was obtained from the maceration of $200 \mathrm{mg}$ of fresh leaf tissue in liquid nitrogen (Bonacina et al., 2017). The activity of the enzymes was expressed in enzymatic units. One unit of the enzyme activity (UA) was defined as the amount of enzyme that causes an increase of 0.001 unit of absorbance per minute, expressed as UA $\min ^{-1} \mathrm{mg}^{-1}$ of soluble protein.

Superoxide dismutase activity (EC 1.15.1.1) was determined by measuring its ability to inhibit the photochemical reduction of nitroblue tetrazolium (NBT), as described by Giannopolitis and Ries (1977). The results are expressed as $\mathrm{UA} \mathrm{g}^{-1}$ fresh weight $(\mathrm{FW}) \mathrm{min}^{-1}$. Catalase activity was (EC 1.11.1.6) determined by the $\mathrm{H}_{2} \mathrm{O}_{2}$ consumption, monitored by recording the absorbance at $260 \mathrm{~nm}$ at the time of $\mathrm{H}_{2} \mathrm{O}_{2}$ addition and $1 \mathrm{~min}$ later (Havir \& McHale, 1987; Anderson et al., 1995). The CAT activity was expressed in mmol $\mathrm{H}_{2} \mathrm{O}_{2} \mathrm{~g}^{-1} \mathrm{FW}$ $\mathrm{min}^{-1}$. Ascorbate peroxidase activity EC 1.11.1.11) was determined as described by Nakano \& Asada (1981). The results were expressed in mmol ascorbate $\mathrm{g}^{-1} \mathrm{FW} \mathrm{min}^{-1}$.

All enzymes were evaluated using 96-well flat-bottomed ELISA plates. In both assays, three technical replicates and three biological replicates were used. The absorbance was recorded using a spectrophotometer (UV-VIS Spectra Max Plus) with SoftMax Pro program 6.5.1. From the data, graphs were generated, and the standard deviation $(\mathrm{n}=9)$ for each treatment was also calculated.

\subsection{Statistical Analysis}

The data for the morphological characteristics and the antioxidant activity were subjected to the Shapiro-Wilk normality test. When the data were not normally distributed, they were analyzed using the Kruskal-Wallis test (p $\leq 0.05)$ in Statistica ${ }^{\circledR}$ software. Normally distributed data were analyzed using analysis of variance $(\mathrm{p} \leq 0.05)$, and the means were compared by Tukey's test $(\mathrm{p} \leq 0.05)$ using SISVAR $^{\circledR} 5.6$ software (Ferreira, 2011).

\section{Results and Discussion}

\subsection{Different Compositions of MS Medium}

The MS medium is the main culture medium used in the micropropagation of plants with high levels of nutrients such as nitrate, ammonium, phosphorus, potassium, micronutrients, vitamins, and amino acids (Murashige \& Skoog, 1962). When used in its original composition, the medium is said to be in its full strength. However, the explants often do not express their maximum development under these conditions (George et al., 2008). Thus, adjustments are required, mainly in the concentration of mineral salts (Greenway et al., 2012). These mineral salts regulate the growth and morphology of the plant, providing essential nutrients. 
Most micropropagation studies have reported that the application of factors isolated from the culture medium, and the responses obtained in previous assays, are not always replicated because of the effect of micropropagation protocol composition on explant growth. Thus, it is necessary to investigate how the morphogenic responses are modified with the composition of the culture medium, and how this can alter the metabolism of plants under in vitro conditions (Grout, 2017).

The results of the assays in the present study were somewhat different from those reported in previous studies because of the interaction effects with the culture medium. These interactions are complex and often difficult to explain, because the responses are inherent to each plant species. For the characteristics measured in this assay, no significant effect of the culture medium was reported only for the oxidized plants. The other characteristics were significantly $(\mathrm{p} \leq 0.05)$ affected by the different culture media. In general, the contamination was very low, suggesting that the asepsis method used was efficient for disinfection of the explants (Table 3). The emission of new shoots, one of the main characteristics of the in vitro micropropagation process, was potentiated in this experiment. The M4 medium resulted in double shoots (4.00) compared with the M2 and M5 media, and these were larger than those obtained in the M1 and M3 media, which practically did not result in any new shoots (Table 3). In addition, there was an increase in the number of leaves (13.0) and the number of roots (7.0), which were double in number than those obtained the M2 medium (Table 3). We emphasize that this culture medium was also shown to be efficient for the development of explants in the studies by Antoniazzi et al. (2016) and Ferrari et al. (2016).

When a plant initiates the organogenesis process, the observed response is the result of the interaction between the medium composition and the growth regulators (George et al., 2008). These factors associated with the plant genotype result in the observed phenotype (Grout, 2017). The emission of a greater number of leaves, shoots, and roots in C. longa explants in the M4 culture medium indicated a major action of growth regulators, especially cytokinins, in a combination with a balanced amount of nutrients (George et al., 2008) and absence of activated charcoal addition.

The signaling role for cytokinin-induced sprout emission was elucidated in Arabidopsis thaliana plants (Tank \& Thaker, 2011). When cytokinins bind to AHK membrane receptors, a series of events is initiated by protein phosphorylation. This signal reaches up to the CDKA genes, which are involved in cell cycle control-G1/S and G2/transitions thus, intensifying the number of mitoses. Moreover, other genes linked to organogenesis, such as WIND1, BBM, and AP2/ERT, receive signals from cytokinins, and it is possible that these mechanisms are involved in sprouting of $C$. longa plants (Tank \& Thaker, 2011). Finally, auxins can also act on the genes associated with the emission of shoots, such as STM and WUS (Neelakandan \& Wang, 2012). Although all culture media were supplemented with growth regulators except for control, we affirmed that the response observed in the $C$. longa explants was a result of the interaction among these regulators, the genotype, and the medium composition. This is evidenced by the absence of additional activated carbon, which can adsorb the growth regulators of the culture medium (Thomas, 2008), and by the smaller amount of nitrogen, which is more suitable for the root emission (George et al., 2008).

On the other hand, the M1 medium (full-strength MS medium and $30 \mathrm{~g} \mathrm{~L}^{-1}$ sucrose) optimized the dry mass accumulation and length of shoots. In turn, a reduction in the amount of mineral salts of the medium (M3 and M4) resulted in an increase in the root dry mass, collar diameter, and relative chlorophyll index (Table 3). The production of dry matter in plants is mainly associated with the presence of nitrogen and other minerals salts (George et al., 2008). The M1 medium was the only medium at full strength, and this should have benefited the accumulation of dry matter in the plants. Similarly, Ferrari et al. (2016) and Gato et al. (2017) also showed that the increase of mineral salts in the medium potentiated the growth of C. longa and Zingiber spectabile Griff plants.

In vitro growth and root mass were observed to generally increase in the presence of a lower concentration of salts. The medium with $70 \%$ salts and $60 \mathrm{~g} \mathrm{~L}^{-1}$ sucrose (M5) was toxic to the roots, and significantly reduced the number and dry mass of the roots. Brondani et al. (2014) reported that interference by the osmotic potential of the medium compromises the formation of roots, as they are the first organ to come into contact with the medium. The roots can dehydrate or undergo cellular collapse if the osmotic potential of the medium is very high (Silva et al., 2017).

Another hypothesis is the effect of antagonistic or synergistic relationships among the nutrients. In this context, George et al. (2008) reported that high concentrations of phosphate reduce the absorption of elemental forms of $\mathrm{Zn}, \mathrm{Fe}$, and $\mathrm{Cu}$. At higher concentrations of $\mathrm{K}^{+}, \mathrm{Ca}^{2+}$, and $\mathrm{Mg}$, the absorption of phosphate ions decreases if the $\mathrm{pH}$ of the solution becomes slightly alkaline, which may compromise root growth. It is possible that the 
combination of these factors resulted in the responses observed in M3 and M5 media. In agreement with our results, an increase in the root biomass of Zingiberaceae family species was reported when the concentration of salts in the medium was reduced by 50\% and 25\% (Abbas et al., 2011; Santos et al., 2017; Haque \& Ghosh, 2018).

Table 3. Different formulations of MS medium on Curcuma longa growth in vitro: number of shoots (NS); number of leaves (NL); number of roots (NR); relative chlorophyll index (RCI); shoot length (SL); root collar diameter (CD); shoot dry mass (SDM); and root dry mass (RDM)

\begin{tabular}{lllllllll}
\hline Treatments & NS & NL & NR & RCI & SL $(\mathrm{mm})$ & CD $(\mathrm{mm})$ & SDM $(\mathrm{g})$ & RDM $(\mathrm{g})$ \\
\hline M1 & $0.00 \pm 0 \mathrm{~b}$ & $9.75 \pm 1 \mathrm{bc}$ & $6.25 \pm 1 \mathrm{ab}$ & $21.24 \pm 6 \mathrm{ab}$ & $96.04 \pm 0 \mathrm{a}$ & $10.76 \pm 2.8 \mathrm{a}$ & $0.58 \pm 0 \mathrm{a}$ & $0.31 \pm 6.4 \mathrm{c}$ \\
M2 & $1.75 \pm 1 \mathrm{~b}$ & $7.25 \pm 1 \mathrm{c}$ & $5.75 \pm 1 \mathrm{~b}$ & $17.75 \pm 0.3 \mathrm{~b}$ & $49.62 \pm 0 \mathrm{c}$ & $4.63 \pm 0.5 \mathrm{~b}$ & $0.18 \pm 0 \mathrm{e}$ & $0.31 \pm 0.3 \mathrm{c}$ \\
M3 & $0.50 \pm 1 \mathrm{~b}$ & $10.75 \pm 2 \mathrm{ab}$ & $4.00 \pm 0 \mathrm{c}$ & $24.85 \pm 0 \mathrm{a}$ & $79.37 \pm 0 \mathrm{~b}$ & $12.99 \pm 1.8 \mathrm{a}$ & $0.28 \pm 0 \mathrm{c}$ & $0.38 \pm 0 \mathrm{a}$ \\
M4 & $4.00 \pm 0 \mathrm{a}$ & $13.00 \pm 0 \mathrm{a}$ & $7.00 \pm 0 \mathrm{a}$ & $20.10 \pm 0 \mathrm{ab}$ & $73.98 \pm 0 \mathrm{~b}$ & $5.08 \pm 0 \mathrm{~b}$ & $0.26 \pm 0 \mathrm{~d}$ & $0.34 \pm 0 \mathrm{~b}$ \\
M5 & $1.25 \pm 2 \mathrm{~b}$ & $10.75 \pm 1 \mathrm{ab}$ & $4.50 \pm 1 \mathrm{c}$ & $21.10 \pm 0 \mathrm{ab}$ & $76.73 \pm 0 \mathrm{~b}$ & $6.35 \pm 0.2 \mathrm{~b}$ & $0.38 \pm 0 \mathrm{~b}$ & $0.12 \pm 0 \mathrm{~d}$ \\
\hline
\end{tabular}

Note. * Means followed by the same letter in the column do not differ by Tukey test $(\mathrm{p} \leq 0.05)$.

M1-100\% MS, $30 \mathrm{~g} \mathrm{~L}^{-1}$ sucrose and absence of activated charcoal; M2-50\% MS, $30 \mathrm{~g} \mathrm{~L}^{-1}$ sucrose and absence of activated charcoal; M3-50\% MS, $60 \mathrm{~g} \mathrm{~L}^{-1}$ sucrose and $4.5 \mathrm{~g} \mathrm{~L}^{-1}$ activated charcoal; M4-70\% $\mathrm{MS}, 30 \mathrm{~g} \mathrm{~L}^{-1}$ sucrose and absence of activated charcoal; M5-70\% MS, $60 \mathrm{~g} \mathrm{~L}^{-1}$ sucrose and $4.5 \mathrm{~g} \mathrm{~L}^{-1}$ activated charcoal. All treatments except $\mathrm{T} 1$ received equal doses of BAP (8.89), NAA (2.16) and 0.92 (KIN).

The highest amount of $\mathrm{N}$ (37.5) was observed in M3 medium (Table 4), which also yielded the higher chlorophyll index. These results are complementary because, together with $\mathrm{Mg}, \mathrm{N}$ is part of the molecular composition of chlorophyll (Lemaire, 2015).

It was not possible to measure the amount of $\mathrm{N}$ in $\mathrm{M} 4$ medium, but $3.0 \mathrm{mg} \mathrm{kg}{ }^{-1}$ of calcium and the lowest amount of copper (1.9) and zinc (32.1) were noted in this medium (Table 4). In M1 medium, which presented the highest biomass production, the potassium content $\left(9.10 \mathrm{~g} \mathrm{~kg}^{-1}\right)$ was lower than in the other treatments. The amount of nitrogen remained above $30 \mathrm{~g} \mathrm{~kg}^{-1}$, calcium and copper remained above $4.0 \mathrm{mg} \mathrm{kg}^{-1}$, and zinc was more than $60.0 \mathrm{mg} \mathrm{kg}^{-1}$ (Table 4).

The highest biomass obtained in plants in M1 medium can be explained, in part, by the absorption of nutrients such as nitrogen, a component of chlorophyll (Lemaire, 2015), and calcium, a component of the middle lamella of plant cell wall and a modulator of calmodulin (White \& Broadley, 2003). Copper and zinc, in addition to acting as co-factors of several enzymes, have a role in the final stage of lignin production in plants, as they regulate important enzymes of this process (Demotes-Mainard et al., 2008; Yruela, 2009). Studies on medicinal plants have revealed that the plants receiving extra doses of these micronutrients in the culture medium form more biomass in the shoots and contain fewer abnormal plantlets (Trettel et al., 2017; Trettel et al., 2018). In this study, no extra dose of micronutrients was added. However, the M1 medium was at full strength and had no activated carbon.

Initially, it was assumed that the medium containing actived charcoal land higher concentrations of sucrose should favor the growth of $C$. longa. Previous studies have shown that species of Zingiberaceae grow best in MS medium at full strength, supplemented with $60 \mathrm{~g} \mathrm{~L}^{-1}$ sucrose (Jala, 2012; Ferrari et al., 2016). Actived charcoal is added to restrict a possible toxic effect of the released compounds. According to Thomas (2008), actived charcoal can retain the toxic substances present in the medium, but can also adsorb vitamins, growth regulators, and especially, micronutrients such as $\mathrm{Cu}$ and $\mathrm{Zn}$. About the responses verified in shoot growth analyzes despite M2 and M4 medium revealed low levels of $\mathrm{Cu}$ and $\mathrm{Zn}$ (Table 4), higher amounts of shoots and leaves were verified in this medium with the absence of actived charcoal and lower amount of sucrose.

In this case, the actived charcoal did not restrict $\mathrm{Cu}$ and $\mathrm{Zn}$ uptake, as M3 and M5 media had higher amounts of these micronutrients (Table 4). These results corroborate those reported by Trettel et al. (2018b), where Ocimum basilicum plantlets maintained in MS medium with $60 \mathrm{~g} \mathrm{~L}^{-1}$ of sucrose and $4.5 \mathrm{~g} \mathrm{~L}^{-1}$ of actived charcoal did not show an increased plantlets growth, and these micronutrients did not contribute to adsorption of $\mathrm{Cu}$ and $\mathrm{Zn}$.

It is noteworthy that in this experiment the reduction of salts in the MS medium with the supplementation of higher concentrations of growth regulators negatively interfered the growth response of shoots in M3 and M5 media, not be detrimental to the growth of the root system that was increased in M3. As mentioned before, 
Zingiberaceae tend to grow better in medium with double the usual dose of sucrose. However, this was not the case for $C$. longa, as when the strength of the medium was reduced, the concentration of growth regulators increased.

Table 4. Macro and micronutrients quantified in the shoots of Curcuma longa in the presence of different formulations of the medium Murashige and Skoog

\begin{tabular}{lllllc}
\hline Treatments & $\mathrm{N}$ & $\mathrm{K}$ & $\mathrm{Ca}$ & $\mathrm{Cu}$ & $\mathrm{Zn}$ \\
\hline & $----------------\mathrm{g} \mathrm{kg}^{-1}$ & -------------- & $--------\mathrm{mg} \mathrm{kg}^{-1}--------$ \\
M1 & 32.70 & 9.10 & 4.0 & 4.2 & 60.0 \\
M2 & 29.50 & 25.50 & 4.5 & 2.4 & 45.1 \\
M3 & 37.50 & 25.10 & 3.8 & 5.0 & 45.8 \\
M4 & - & 27.60 & 3.0 & 1.9 & 32.1 \\
M5 & 35.50 & 35.45 & 2.7 & 4.5 & 57.2 \\
\hline
\end{tabular}

Note. M1-100\% MS, $30 \mathrm{~g} \mathrm{~L}^{-1}$ sucrose and absence of activated charcoal; M2-50\% MS, $30 \mathrm{~g} \mathrm{~L}^{-1}$ sucrose and absence of activated charcoal; M3-50\% MS, $60 \mathrm{~g} \mathrm{~L}^{-1}$ sucrose and $4.5 \mathrm{~g} \mathrm{~L}^{-1}$ activated charcoal; M4-70\% MS, 30 g $\mathrm{L}^{-1}$ sucrose and absence of activated charcoal; M5-70\% MS, $60 \mathrm{~g} \mathrm{~L}^{-1}$ sucrose and $4.5 \mathrm{~g} \mathrm{~L}^{-1}$ activated charcoal. All treatments except T1 received equal doses of BAP (8.89), NAA (2.16) and 0.92(KIN).

The highest percentage of antioxidant activity was observed in M1 (18.6 \pm 1.5$),$ M2, M5, and M4 medium, in this order. The lowest mean (5.72 \pm 1.42$)$ was observed in M3 medium (Figure 1).

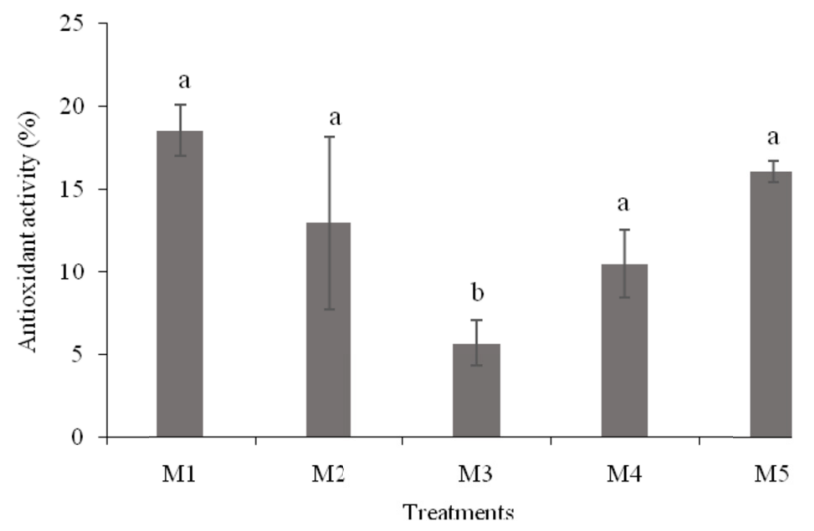

Figure 1. Antioxidant activity of Curcuma longa leaves as a function of different formulations of MS medium Note. * Means followed by the same letter in the column do not differ by Tukey test $(\mathrm{p} \leq 0.05)$.

M1-100\% MS, $30 \mathrm{~g} \mathrm{~L}^{-1}$ sucrose and absence of activated charcoal; M2-50\% MS, $30 \mathrm{~g} \mathrm{~L}^{-1}$ sucrose and absence of activated charcoal; M3-50\% MS, $60 \mathrm{~g} \mathrm{~L}^{-1}$ sucrose and $4.5 \mathrm{~g} \mathrm{~L}^{-1}$ activated charcoal; M4-70\% $\mathrm{MS}, 30 \mathrm{~g} \mathrm{~L}^{-1}$ sucrose and absence of activated charcoal; M5-70\% MS, $60 \mathrm{~g} \mathrm{~L}^{-1}$ sucrose and $4.5 \mathrm{~g} \mathrm{~L}^{-1}$ activated charcoal. All treatments except T1 received equal doses of BAP (8.89), NAA (2.16) and 0.92 (KIN).

C. longa produces a series of secondary metabolites in the rhizome and the leaves, particularly, the curcuminoids, which give orange coloration to rhizomes and terpenes (Hwang et al., 2016). The composition of such secondary metabolites varies according to the genotype and plant location (Zhang et al., 2017). However, some compounds have been reported frequently in $C$. longa, such as curcuminoids (Sueth-Santiago et al., 2015), $\beta$-sesquiphellandrene, and $\alpha$-sesquiphellandrene, as the major compounds in rhizomes (Zhang et al., 2017) and leaves (Priya et al., 2012).

The antioxidant capacity of these compounds against free radicals in plant cells is well recognized (Braga et al., 2018). Initially, it was assumed that plantlets growing in a less propitious environment would present higher antioxidant activity, but this hypothesis was not confirmed. Nevertheless, plantlets developed in M1 and M4 media presented higher averages for the antioxidant activity than those from other treatments. However, it must be noted that these compounds of secondary metabolism are not the only mechanism of action against free radicals (Sanchez-Moreno, 2002; Gill \& Tuteja, 2010). The plant cell has several other defense mechanisms, 
such as the removing enzymes of radicals (Noctor et al., 2018), some of which were evaluated in this study. It is possible that another defense mechanism is more effective in combating free radicals than secondary metabolites.

We also believe that the responses to antioxidant activities could be related to the elicitation of the medium, mainly M1 (Table 5). In this case, the medium would favor the production of compounds that act as antioxidants in the plant. Elicitors have been used in plant tissue culture to stimulate the production of secondary compounds (Patel \& Krishnamurthy, 2013). If the antioxidant compounds of $C$. longa were stimulated, it would be natural for the tests to demonstrate a higher antioxidant activity, as these compounds react with the radical DPPH to neutralize it (Sanchez-Moreno, 2002).

This hypothesis is corroborated by the results of Abraham et al. (2011), who observed in Curcuma mangga maintained in vitro, that different concentrations of yeast extract did not favor the growth of this species, but concentrations above $3.5 \mathrm{mg} \mathrm{L}^{-1}$ more than doubled the production of total phenolic compounds compared with the control (5.0 ug GAE/mg DW).

The APX enzyme showed an activity above $0.4 \mathrm{mM} \mathrm{g}^{-1} \mathrm{FW}$ in all media, except for M1, which showed a slightly lower activity than this value (Figure 2). CAT was the enzyme with the most variation in activity across treatments, which can be attributed to the fact that CAT works to remove the peroxide and oxidize it in water, and thus, the activity would be a function of the $\mathrm{H}_{2} \mathrm{O}_{2}$ concentration in each culture medium (Gill \& Tuteja, 2010). The highest mean was observed in M1 and M4 media (above $0.2 \mathrm{mM} \mathrm{g}^{-1} \mathrm{FW}$ ) (Figure 2), which were also the ones that presented better growth performance than others (Table 3). SOD had an almost constant activity across all treatments. Its activity was higher than $1200 \mathrm{mM} \mathrm{mg}^{-1} \mathrm{FW}$ in all treatments except M5, where the value was slightly lower (Figure 2). SOD has been shown to have high activity, because it is the first line of defense against free radicals (Schieber \& Chandel, 2014). The singlet oxygen is reduced by this enzyme or is transformed in $\mathrm{H}_{2} \mathrm{O}_{2}$ by enzymes such as APX and peroxiredoxins (PRX) (Noctor et al., 2018). Catalase acts by oxidizing $\mathrm{H}_{2} \mathrm{O}_{2}$ peroxide into water and an oxidized radical, thus, completing the cell cleansing cycle; a single molecule is effective against thousands of $\mathrm{H}_{2} \mathrm{O}_{2}$ molecules (Gill \& Tuteja, 2010).
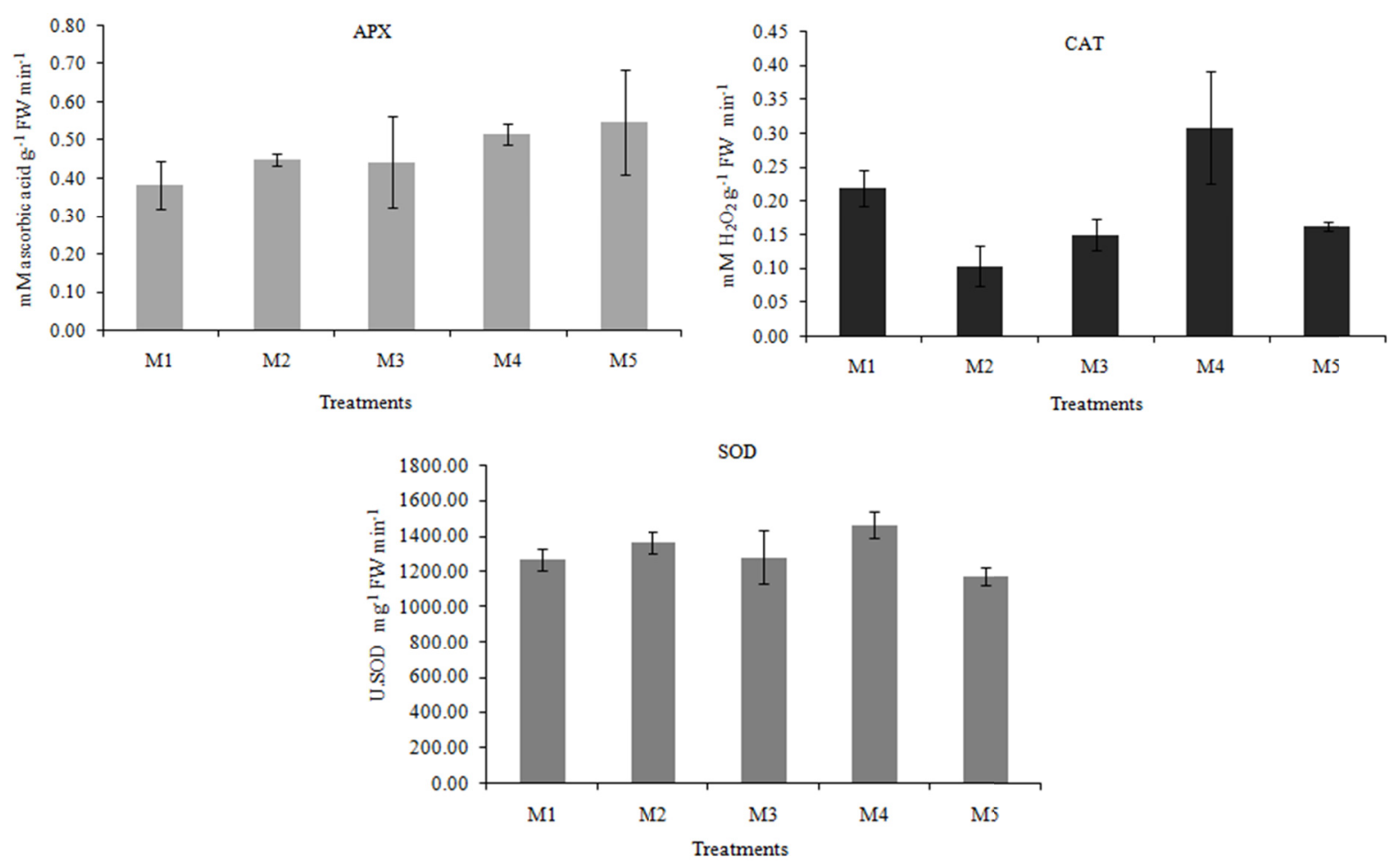

Figure 2. Enzymatic activity of APX, CAT and SOD of Curcuma longa leaves as a function of different formulations of MS medium

Note. M1-100\% MS, $30 \mathrm{~g} \mathrm{~L}^{-1}$ sucrose and absence of activated charcoal; M2-50\% MS, $30 \mathrm{~g} \mathrm{~L}^{-1}$ sucrose and absence of activated charcoal; M3-50\% MS, $60 \mathrm{~g} \mathrm{~L}^{-1}$ sucrose and $4.5 \mathrm{~g} \mathrm{~L}^{-1}$ activated charcoal; M4-70\% MS, $30 \mathrm{~g}$ 
$\mathrm{L}^{-1}$ sucrose and absence of activated charcoal; M5- 70\% MS, $60 \mathrm{~g} \mathrm{~L}^{-1}$ sucrose and $4.5 \mathrm{~g} \mathrm{~L}^{-1}$ activated charcoal. All treatments except T1 received equal doses of BAP (8.89), NAA (2.16) and 0.92 (KIN).

\subsection{Effect of Different Concentrations of Auxins and Cytokinins}

The plant hormones act in cell division, senescence, metabolic synthesis, and several other aspects of the plant development process (Prins et al., 2013; Souza \& Lüettge, 2015). Some studies have indicated that high concentrations of BAP can reduce the size of shoots during the micropropagation of herbaceous plants (Antoniazzi et al., 2016). Other trials for plants of the Zingiberaceae family found that concentrations lower than $2.0 \mathrm{mg} \mathrm{L}^{-1}$ of BAP were better for plantlets development (Aros et al., 2017), which was also corroborated by the results of this study.

The regulators and their concentrations affected most of the evaluated characteristics, and only the number of roots was not different across treatments (Table 5). M3 (8.88 BAP, $0.92 \mathrm{KIN}, 2.16 \mathrm{NAA}$ ) showed the best results in terms of the number of shoots (7.75), leaves (35), and shoot length $(88.57 \mathrm{~mm})$, followed by M4 and M2 (Table 5). There was a decrease in shoot numbers with increasing amounts of regulators (T5: 17.76 BAP, 1.38 KIN, 7.20 NAA). The same was observed with the number of leaves and collar diameter (Table 5).

Collar diameter, shoot dry mass, and root dry mass were the highest in $\mathrm{M} 2(4.44 \mu \mathrm{M}$ of BAP, $0.46 \mu \mathrm{M}$, of KIN, and $1.08 \mu \mathrm{M}$ of NAA), followed by M3 and M1 (Table 5). The root and shoot dry mass were twice the value in M2 medium relative to the M5 medium, where the worst means were observed. The decrease in shoot dry mass is directly related to the lower number of shoots observed with the higher doses of regulators used in this assay and may be indicative of the phytotoxicity of the BAP growth regulator (George et al., 2008).

The organogenesis process depends on the concentration of each regulator in the medium, and each part of the plant has a different response to changes in auxin and cytokinin concentrations (Pozo et al., 2005). Plant cells in culture have the unique potential to alter their developmental program in order to adapt to in vitro conditions. This is because the response of this cell to hormones will depend on the activation of specific transcription factors, sensitivity to auxin, transporters, and membrane receptors (Neelakandan \& Wang, 2012). Therefore, it was expected to have a differentiated response to the concentration of regulators in shoot growth and $C$. longa root system.

Table 5. Different concentrations of auxins and cytokinins in the growth of Curcuma longa: number of shoots (NS); number of leaves (NL); number of roots (NR); relative chlorophyll index (RCI); shoot length (SL); root collar diameter (CD); shoot dry mass (SDM); and root dry mass (RDM)

\begin{tabular}{lllllllll}
\hline Treatments & NS & NL & NR & RCI & SL $(\mathrm{mm})$ & CD $(\mathrm{mm})$ & SDM $(\mathrm{g})$ & RDM $(\mathrm{g})$ \\
\hline T1 & $2.50 \pm 1 \mathrm{~b}$ & $22.00 \pm 4 \mathrm{~b}$ & $8.50 \pm 1 \mathrm{a}$ & $19.05 \pm 2 \mathrm{~b}$ & $71.75 \pm 6 \mathrm{~b}$ & $6.46 \pm 0 \mathrm{bc}$ & $0.41 \pm 0 \mathrm{~b}$ & $0.37 \pm 0,1 \mathrm{c}$ \\
T2 & $7.00 \pm 1 \mathrm{a}$ & $26.00 \pm 4 \mathrm{ab}$ & $7.75 \pm 1 \mathrm{a}$ & $26.51 \pm 5 \mathrm{ab}$ & $81.84 \pm 7 \mathrm{ab}$ & $8.29 \pm 1 \mathrm{a}$ & $0.46 \pm 0,1 \mathrm{a}$ & $0.46 \pm 0 \mathrm{a}$ \\
T3 & $7.75 \pm 1 \mathrm{a}$ & $35.00 \pm 6 \mathrm{a}$ & $7.75 \pm 2 \mathrm{a}$ & $27.95 \pm 7 \mathrm{ab}$ & $88.57 \pm 3 \mathrm{a}$ & $6.02 \pm 0 \mathrm{bc}$ & $0.35 \pm 0 \mathrm{c}$ & $0.38 \pm 0,1 \mathrm{~b}$ \\
T4 & $7.25 \pm 1 \mathrm{a}$ & $32.25 \pm 6 \mathrm{a}$ & $8.25 \pm 1 \mathrm{a}$ & $23.74 \pm 5 \mathrm{ab}$ & $80.39 \pm 6 \mathrm{ab}$ & $7.12 \pm 1 \mathrm{ab}$ & $0.31 \pm 0,2 \mathrm{~d}$ & $0.36 \pm 0 \mathrm{~d}$ \\
T5 & $3.50 \pm 1 \mathrm{~b}$ & $21.50 \pm 3 \mathrm{~b}$ & $7.25 \pm 1 \mathrm{a}$ & $28.76 \pm 1 \mathrm{a}$ & $90.48 \pm 3 \mathrm{a}$ & $5.27 \pm 1 \mathrm{c}$ & $0.23 \pm 0 \mathrm{e}$ & $0.29 \pm 0 \mathrm{e}$ \\
\hline
\end{tabular}

Note. * Means followed by the same letter in the column do not differ by Tukey test $(\mathrm{p} \leq 0.05)$.

T1-control; T2-4.44 (BAP) + $0.46(\mathrm{KIN})+1.08(\mathrm{NAA}) ; \mathrm{T} 3-8.88(\mathrm{BAP})+0.92(\mathrm{KIN})+2.16(\mathrm{NAA}) ; \mathrm{T} 4-13.32$ $(\mathrm{BAP})+3.24(\mathrm{NAA}) ; \mathrm{T} 5-17.76(\mathrm{BAP})+1.38(\mathrm{KIN})+7.20(\mathrm{NAA})$.

High availability of $\mathrm{N}\left(40.22 \mathrm{~g} \mathrm{~kg}^{-1}\right)$ and $\mathrm{Zn}\left(45.50 \mathrm{mg} \mathrm{kg}^{-1}\right)$ was verified in M3 medium (Table 6), which presented good results for leaf number, as well as the number and length of shoots (Table 5), however, a low amount of $\mathrm{Cu}(0.60)$ was observed in this treatment. With the increase in the doses of regulators, an increase in the levels of potassium absorption by the $C$. longa was observed, whereas calcium levels remained similar in all culture media (Table 6). 
Table 6. Macro and micronutrients quantified in the shoots of Curcuma longa in the presence of different growth regulators and concentrations

\begin{tabular}{|c|c|c|c|c|c|}
\hline Treatments & $\mathrm{N}$ & $\mathrm{K}$ & $\mathrm{Ca}$ & $\mathrm{Cu}$ & $\mathrm{Zn}$ \\
\hline & \multicolumn{3}{|c|}{ - } & \multicolumn{2}{|c|}{ - } \\
\hline $\mathrm{T} 1$ & 38.55 & 13.01 & 3.61 & 1.00 & 29.60 \\
\hline $\mathrm{T} 2$ & 29.06 & 35.70 & 3.88 & 1.40 & 43.10 \\
\hline $\mathrm{T} 3$ & 40.22 & 39.40 & 3.90 & 0.60 & 45.50 \\
\hline $\mathrm{T} 4$ & 32.90 & 41.90 & 3.30 & 1.70 & 38.00 \\
\hline $\mathrm{T} 5$ & 39.00 & 42.00 & 3.80 & 1.40 & 44.00 \\
\hline
\end{tabular}

Note. T1-control; T2-4.44 (BAP) + $0.46(\mathrm{KIN})+1.08$ (NAA); T3-8.88 (BAP) + 0.92 (KIN) + 2.16 (NAA); T4-13.32 (BAP) + 3.24 (NAA); T5-17.76 (BAP) + $1.38($ KIN $)+7.20($ NAA)

It was expected that the treatments less favorable to the explant growth would present higher antioxidant activity, but this was not observed. In particular, the M3 culture medium (Figure 3), which showed good results for several characteristics analyzed (Table 6), also presented the highest mean antioxidant activity. M2, followed by M5, presented the lowest antioxidant activity (Figure 3).

Previous studies have also reported an increase in antioxidant activity in unexpected culture media. Although the antioxidant activity is usually associated with the state of stress in the plant (Demidchik, 2015), our results could not corroborate this hypothesis, as the plants of this treatment presented larger amounts of leaves and shoots, and satisfactory levels of biomass, compared with the other treatments. Therefore, our results reinforced the hypothesis, that in this case, antioxidant compounds not detected by the DPPH method could be acting against the reactive oxygen species, especially in M3 medium. This hypothesis was also presented by Abraham et al. (2011), who did not observe a correlation between the total content of phenolics and the elimination of free radicals analyzed by the DPPH method.

A second hypothesis is that the responses found in our study may be indicative of elicitation. Thus, the medium could have functioned as an elicitor, leading to an increased production of secondary metabolic compounds (Sanchez-Moreno, 2002). Growth regulators have been described in the literature as eliciting agents (Karalija et al., 2016). For example, a report by Coste et al. (2011) showed that sprouts of Hypericum hirsutum and Hypericum maculatum in MS medium supplemented with BAP $\left(0.4 \mathrm{mg} \mathrm{L}^{-1}\right)$ or KIN $\left(0.4 \mathrm{mg} \mathrm{L}^{-1}\right)$ showed an approximately two-fold increase in hypericin production compared with the control. Alpinia zerumbet, exposed to a solution of methyl jasmonate (MeJA) in the culture medium for 3 and 10 days, presented a remarkable increase of terpinen-4-ol (18.01\% and $14.75 \%$, respectively), compared with the case in the absence of regulator (Victório et al., 2011).

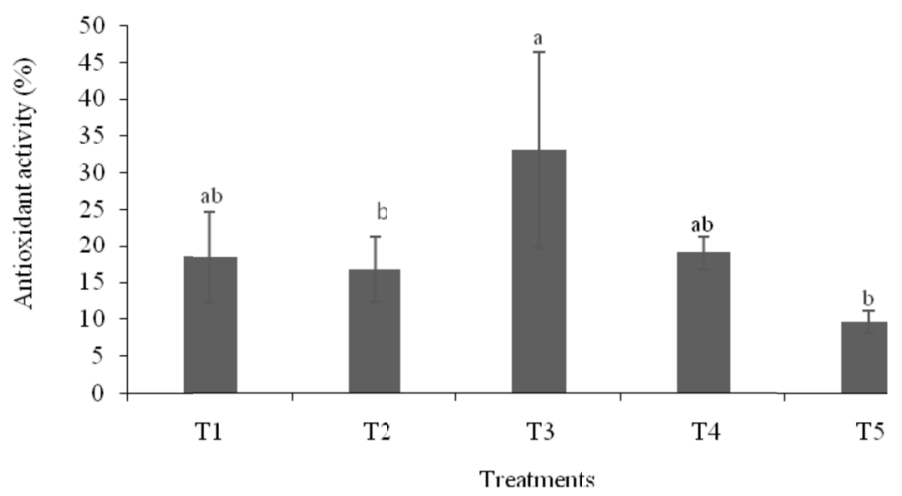

Figure 3. Antioxidant activity of Curcuma longa leaves as a function of different growth regulators and concentrations

Note. * Means followed by the same letter in the column do not differ by Tukey test $(\mathrm{p} \leq 0.05)$.

T1-control; T2-4.44 (BAP) + $0.46(\mathrm{KIN})+1.08(\mathrm{NAA})$; T3-8.88 (BAP) + $0.92(\mathrm{KIN})+2.16(\mathrm{NAA})$; T4-13.32 $(\mathrm{BAP})+3.24$ (NAA); T5-17.76 (BAP) + $1.38(\mathrm{KIN})+7.20$ (NAA). 
Reactive oxygen species (ROS), including superoxide anion $\left(\mathrm{O}_{2}{ }^{-}\right)$, hydrogen peroxide $\left(\mathrm{H}_{2} \mathrm{O}_{2}\right)$, and hydroxyl radicals $(\cdot \mathrm{OH})$ (Demidchik, 2015), are byproducts of aerobic activity metabolism (Schieber \& Chandel, 2014). The main causes of oxidative stress include the imbalance between ROS formation and cell detoxification, the biosynthesis of ROSs as a constituent part of stress signaling, and the immune response to defense and adaptation (Demidchik, 2015). Thus, any free radical scavenging activity in the cell would be related to factors that cause the formation of these radicals, and to that equilibrium for the action of each enzyme.

The highest enzymatic activity of APX was evident in media with mean values higher than $0.5 \mathrm{mM}$. For CAT, the highest activity was observed in M2 and M5 media (Figure 4). On the other hand, SOD had a low activity in the M1 and M2 media (below 1000 units activity), with similar levels observed across the other culture media (Figure 4). This similarity across media and higher values of SOD activity may be related to the fact that this enzyme is the first line of defense against $\mathrm{H}_{2} \mathrm{O}_{2}$ radicals in the cell (Schieber \& Chandel, 2014).

Again, we did not find linearity in the results, and this could be because the action of the enzymes is linked to the amount of free radicals present in the cell (Demidchik, 2015). As the action of these enzymes is directed to specific reactions, this variation was expected. It should also be emphasized that the cell has other enzymatic mechanisms to control free radicals (Gill \& Tuteja, 2010). Thus, the enzymatic and non-enzymatic mechanisms must act in a balanced way, and the explants could possess another one or two effective ways of controlling these free radicals.
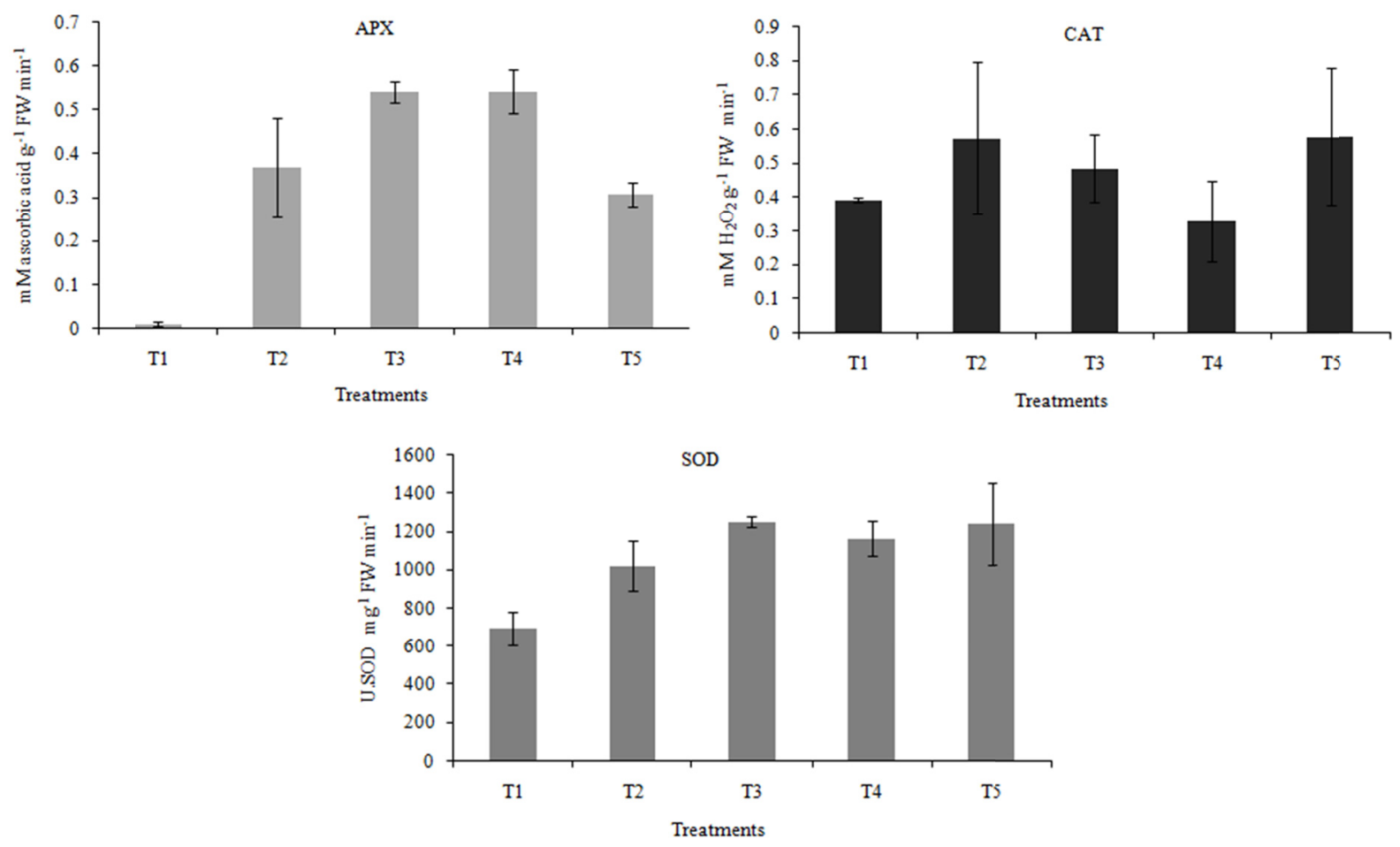

Figure 4. Enzymatic activity of APX, CAT and SOD of Curcuma longa leaves as a function of different growth regulators and concentrations

Note. T1-control; T2-4.44 (BAP) + $0.46(\mathrm{KIN})+1.08(\mathrm{NAA})$; T3-8.88 (BAP) + $0.92(\mathrm{KIN})+2.16(\mathrm{NAA})$; T4-13.32 (BAP) + $3.24(\mathrm{NAA}) ; \mathrm{T} 5-17.76(\mathrm{BAP})+1.38(\mathrm{KIN})+7.20(\mathrm{NAA})$.

\section{Conclusions}

The MS culture medium at $70 \%$ strength, supplemented with $30 \mathrm{~g} \mathrm{~L}^{-1}$ of sucrose, and without the addition of activated carbon, resulted in the highest number of shoots.

The sucrose concentration of $60 \mathrm{~g} \mathrm{~L}^{-1}$, combined with the addition of actived charcoalin half-strength MS medium, resulted in increased root dry mass, root collar diameter, and relative chlorophyll index. 
The root system growth was potentiated in the MS culture medium supplemented with $4.44 \mu \mathrm{M}$ BAP, $0.46 \mu \mathrm{M}$ $\mathrm{KIN}$, and $1.08 \mu \mathrm{M}$ NAA.

The antioxidant activity in the first assay was the highest in the full-strength MS medium supplemented with 30 $\mathrm{g} \mathrm{L}^{-1}$ of sucrose, and without the addition of activated carbon, whereas, in the second assay, it was significantly higher than other treatments in the MS medium supplemented with $8.88 \mu \mathrm{M}$ BAP, $0.92 \mu \mathrm{M}$ KIN, and $2.16 \mu \mathrm{M}$ NAA.

Superoxide dismutase had the highest enzymatic activity in both assays, whereas the enzymatic activity of catalase and ascorbate peroxidase was dependent of the culture media used, with high CAT activity in media M1 and M4 (assay 1), and M2 and M5 (assay 2), and high APX activity in media M5 (assay 1), and M3 and M4 (assay 2).

\section{References}

Abbas, M. S., Taha, H. S., Aly, U. I., El-Shabrawi, H. M., \& Gaber, E. S. I. (2011). In vitro propagation of ginger (Zingiber officinale Rosco). Journal of Genetic Engineering and Biotechnology, 9(2), $165-172$. https://doi.org/10.1016/j.jgeb.2011.11.002

Abraham, F., Bhatt, A., Keng, C. L., Indrayanto, G., \& Sulaiman, S. F. (2011). Effect of yeast extract and chitosan on shoot proliferation, morphology and antioxidant activity of Curcuma mangga in vitro plantlets. African Journal of Biotechnology, 10(40), 7787-7795. https://doi.org/10.5897/AJB10.1261

Anderson, J. W., Johnstone, B. M., \& Cook-Newell, M. E. (1995). Meta-analysis of the effects of soy protein intake on serum lipids. New England Journal of Medicine, 333(5), 276-282. https://doi.org/10.1056/ NEJM199508033330502

Antoniazzi, D., Ferrari, M. P. S., Nascimento, A. B., Silveira, F. A., Pio, L. A. S., Pasqual, M., \& Magalhães, H. M. (2016). Growth regulators, DNA content and anatomy in vitro-cultivated Curcuma longa plantletsss. African Journal of Biotechnology, 15(32), 1711-1725. https://doi.org/10.5897/AJB2016.15445

Aros, D., Vásquez, M., Rivas, C., \& Prat, M. L. (2017). An efficient method for in vitro propagation of Alstroemeria pallid Graham rhizomes. Chilean Journal of Agricultural Research, 77(1), 95-99. https://doi.org/10.4067/S0718-58392017000100012

Bonacina, C., Trevizan, C. B., Stracieri, J., Santos, T. B., Gonçalves, J. E., Gazim, Z. C., \& Souza, S. G. H. (2017). Changes in growth, oxidative metabolism and essential oil composition of lemon balm (Melissa officinalis L.) subjected to salt stress. Australian Journal of Crop Science, 11(12), 1665-1674. https://doi.org/10.21475/ajcs.17.11.12.pne921

Braga, M. C., Vieira, E. C. S., \& Oliveira, T. F. (2018). Curcuma longa L. leaves: Characterization (bioactive and antinutritional compounds) for use in human food in Brazil. Food Chemistry, 265, 308-315. https://doi.org/10.1016/j.foodchem.2018.05.096

Brondani, G. E., Baccarin, F. J. B., Gonçalves, A. N., \& Almeida, M. D. (2014). Nutritional content in Eucalyptus benthamii mini-stump leaves. Acta Scientiarum Agronomy, 36(4), 465-474. https://doi.org/ 10.4025/actasciagron.v36i4.16827

Chen, W., Lu, Y., Gao, M., Wu, J., Wang, A., \& Shi, R. (2011). Anti-angiogenesis effect of essential oil from Curcuma zedoaria in vitro and in vivo. Journal of Ethnopharmacology, 133(1), 220-226. https://doi.org/10.1016/j.jep.2010.09.031

Coste, A., Vlase, L., Halmagyi, A., Deliu, C., \& Coldea, G. (2011). Effects of plant growth regulators and elicitors on production of secondary metabolites in shoot cultures of Hypericum hirsutum and Hypericum maculatum. Plant Cell, Tissue and Organ Culture, 106(2), 279-288. https://doi.org/10.1007/ s11240-011-9919-5

Demidchik, V. (2015). Mechanisms of oxidative stress in plants: From classical chemistry to cell biology. Environmental and Experimental Botany, 109, 212-228. https://doi.org/10.1016/j.envexpbot.2014.06.021

Demotes-Mainard, S., Boumaza, R., Meyer, S., \& Cerovic, Z. G. (2008). Indicators of nitrogen status for ornamental woody plants based on optical measurements of leaf epidermal polyphenol and chlorophyll contents. Scientia Horticulturae, 115(4), 377-385. https://doi.org/10.1016/j.scienta.2007.10.006

Faridah, Q. Z., Abdelmageed, A. H. A., Julia, A. A., \& Hafizah, R. N. (2011). Efficient in vitro regeneration of Zingiber zerumbet Smith (a valuable medicinal plant) plantlets from rhizome bud explants. African Journal of Biotechnology, 10(46), 9303-9308. https://doi.org/10.5897/AJB11.1182 
Ferrari, M. P. S., Antoniazzi, D., Nascimento, A. B., Franz, L. F., Bezerra, C. S., \& Magalhães, H. M. (2016). Evaluation of new protocols to Curcuma longa micropropagation: A medicinal and ornamental specie. Journal of Medicinal Plants Research, 10(25), 367-376. https://doi.org/10.5897/JMPR2016.6109

Ferreira, D. F. (2011). Sisvar: A computer statistical analysis system. Ciência e Agrotecnologia, 35(6), 1039-1042. https://doi.org/10.1590/S1413-70542011000600001

Gato, A. M. G., Silva, S., Ferreira, F. F., Neta, E., Pinheiro, D. D. C. R., \& Assunção, L. M. (2017). Effects of different concentrations of gibberellic acid (AG3) on germination and 6- benzylaminopurine (BAP) on the micropropagation of Zingiber spectabile Griff. Scientia Amazonia, 6(3), 75-82.

George, E. F., Hall, M. A., \& Klerk, G. J. (2008). Plant propagation by tissue culture. Netherland, NT: Springer. https://doi.org/10.1007/978-1-4020-5005-3

Giannopolitis, C. N., \& Ries, S. K. (1977). Superoxide dismutases: I. Occurrence in higher plants. Plant Physiology, 59(2), 309-314. https://doi.org/10.1104/pp.59.2.309

Gill, S. S., \& Tuteja, N. (2010). Reactive oxygen species and antioxidant machinery in abiotic stress tolerance in crop plants. Plant Physiology and Biochemistry, 48(12), 909-930. https://doi.org/10.1016/j.plaphy. 2010.08.016

Girardi, C. G., Debiasi, C., \& Pescador, R. (2007). Aclimatization and development in field of ginger happened of micropropagated and conventional type. Scientia Agraria, 8(2), 205-211. https://doi.org/10.5380/ rsa.v8i2.8373

Greenway, M. B., Phillips, I. C., Lloyd, M. N., Hubstenberger, J. F., \& Phillips, G. C. (2012). A nutrient medium for diverse applications and tissue growth of plant species in vitro. In Vitro Cellular \& Developmental Biology-Plant, 48(4), 403-410. https://doi.org/10.1007/s11627-012-9452-1

Grout, B. (2017). General principles of tissue culture. Encyclopedia of Applied Plant Sciences, 2(2), $437-443$. https://doi.org/10.1016/B978-0-12-394807-6.00143-X

Haque, S. M., \& Ghosh, B. (2018). Micropropagation of Kaempferia angustifolia Roscoe-an aromatic, essential oil yielding, underutilized medicinal plant of zingiberaceae family. Journal of Crop Science and Biotechnology, 21(2), 147-153. https://doi.org/10.1007/s12892-017-0051-0

Havir, E. A., \& McHale, N. A. (1987). Biochemical and developmental characterization of multiple forms of catalase in tobacco leaves. Plant Physiology, 84(2), 450-455. https://doi.org/10.1104/pp.84.2.450

Hwang, K. W., Son, D., Jo, H. W., Kim, C. H., Seong, K. C., \& Moon, J. K. (2016). Levels of curcuminoid and essential oil compositions in turmerics (Curcuma longa L.) grown in Korea. Applied Biological Chemistry, 59(2), 209-215. https://doi.org/10.1007/s13765-016-0156-9

Jala, A. (2012). Effects of NAA BA and sucrose on shoot induction and rapid micropropagation by trimming shoot of Curcuma Longa L. International Transaction Journal of Engineering, Management, \& Applied Sciences \& Technologies, 3(2), 101-109.

Karalija, E., Neimarlija, D., Cakar, J., \& Paric, A. (2016). Elicitation of biomass and secondary metabolite production, antioxidative and antimicrobial potential of basil and oregano induced by BA and IBA application. European Journal of Medicinal Plants, 14(4), 1-11. https://doi.org/10.9734/EJMP/2016/26121

Lemaire, G. (2015). Crop Responses to Nitrogen. Encyclopedia of Sustainability Science and Technology, 1, 1-25. https://doi.org/10.1007/978-1-4939-2493-6_385-3

Magalhães, H. M., Brandão, T. M., Stracieri, J., Jesus, H. F., Mendes, D. S. T., \& Pasqual, M. (2017). Evaluating chemical composition of Butia capitata pulp among various populations and locations using multivariate analysis. African Journal of Biotechnology, 16(38), 1902-1910. https://doi.org/10.5897/AJB2017.16107

Malavolta, E. (1980). Elementos de nutrição mineral de plantas. São Paulo, SP: Agronômica Ceres.

Matkowski, A. (2008). Plant in vitro culture for the production of antioxidants-a review. Biotechnology Advances, 26(6), 548-560. https://doi.org/10.1016/j.biotechadv.2008.07.001

Miachir, J. I., Romani, V. L. M., Amaral, A. F. D. C., Mello, M. O., Crocomo, O. J., \& Melo, M. (2004). Micropropagation and callogenesis of Curcuma zedoaria Roscoe. Scientia Agricola, 61(4), 427-432. https://doi.org/10.1590/S0103-90162004000400012

Murashige, T., \& Skoog, F. (1962). A revised medium for rapid growth and bio assays with tobacco tissue cultures. Physiologia Plantarum, 15(3), 473-497. https://doi.org/10.1111/j.1399-3054.1962.tb08052.x 
Nakano, Y., \& Asada, K. (1981). Hydrogen peroxide is scavenged by ascorbate specific peroxidase in spinach chloroplasts. Plant and Cell Physiology, 22(5), 867-880. https://doi.org/10.1093/oxfordjournals.pcp. a076232

Neelakandan, A. K., \& Wang, K. (2012). Recent progress in the understanding of tissue culture-induced genome level changes in plants and potential applications. Plant Cell Reports, 31(4), 597-620. https://doi.org/ 10.1007/s00299-011-1202-z

Noctor, G., Reichheld, J. P., \& Foyer, C. H. (2018). ROS-related redox regulation and signaling in plants. In Seminars in Cell \& Developmental Biology, 80, 3-12. https://doi.org/10.1016/j.semcdb.2017.07.013

Patel, H., \& Krishnamurthy, R. (2013). Elicitors in plant tissue culture. Journal of Pharmacognosy and Phytochemistry, 2(2), 60-65.

Péret-Almeida, L., Cherubino, A. P. F., Alves, R. J., Dufossé, L., \& Glória, M. B. A. (2005). Separation and determination of the physico-chemical characteristics of curcumin, demethoxycurcumin and bisdemethoxycurcumin. Food Research International, 38(8-9), 1039-1044. https://doi.org/10.1016/ j.foodres.2005.02.021

Pozo, J. C., Lopez-Matas, M. A., Ramirez-Parra, E., \& Gutierrez, C. (2005). Hormonal control of the plant cell cycle. Physiologia Plantarum, 123(2), 173-183. https://doi.org/10.1111/j.1399-3054.2004.00420.x

Prins, C. L., Freitas, S. P., Gomes, M. M. A., Vieira, I. J. C., \& Gravina, G. A. (2013). Citral accumulation in Cymbopogon citratus plant as influenced by N6-benzylaminopurine and light intensity. Theoretical and Experimental Plant Physiology, 25(2), 159-165. https://doi.org/10.1590/S2197-00252013000200008

Priya, R., Prathapan, A., Raghu, K. G., \& Menon, A. N. (2012). Chemical composition and in vitro antioxidative potential of essential oil isolated from Curcuma longa L. leaves. Asian Pacific Journal of Tropical Biomedicine, 2(2), 695-699. https://doi.org/10.1016/S2221-1691(12)60298-6

Raina, V. K., Srivastava, S. K., \& Syamsundar, K.V. (2005). Rhizome and leaf oil composition of Curcuma longa from the lower Himalayan region of northern India. Journal of Essential Oil Research, 17(5), 556-559. https://doi.org/10.1080/10412905.2005.9698993

Ramakrishnan, T. S., \& Sowmini, C. K. (1955). Rhizome and root rot of turmeric caused by Pythium graminicola Sub. Indian Phytopathology, 7(2), 152-159.

Rodrigues, A. A. J., Santos, E. O., Takane, R. J., \& Carvalho, A. C. P. P. (2017). Artificial light and growth regulators on the in vitro etiolation of Cattleya labiata. Revista Ciência Agronomica, 48(2), 296-302. https://doi.org/10.5935/1806-6690.20170034

Rufino, M., Fernandes, F., Alves, R., \& Debrito, E. (2009). Free radical-scavenging behaviour of some north-east Brazilian fruits in a DPPH system. Food Chemistry, 114(2), 693-695. https://doi.org/10.1016/j.foodchem. 2008.09.098

Sanchez-Moreno, C. (2002). Review: Methods used to evaluate the free radical scavenging activity in foods and biological systems. Food Science and Technology International, 8(3), 121-137. https://doi.org/10.1106/ 108201302026770

Santos, E. O., Jesus Rodrigues, A. A., \& Carvalho, A. C. P. P. (2017). Concentrations of the MS medium and auxins on in vitro rooting of the torch ginger (Etlingera elatior). Plant Cell Culture \& Micropropagation, 13(1), 7-14.

Schieber, M., \& Chandel, N. S. (2014). ROS function in redox signaling and oxidative stress. Current Biology, 24(10), 453-462. https://doi.org/10.1016/j.cub.2014.03.034

Sies, H., \& Stahl, W. (1995). Vitamins E and C, beta-carotene, and other carotenoids as antioxidants. The American Journal of Clinical Nutrition, 62(6), 1315-132. https://doi.org/10.1093/ajen/62.6.1315S

Silva, F. J., Nascimento, A. B., Barbosa, L. N., \& Magalhães, H. M. (2017). In vitro cultivation of purple basil Ocimum basilicum L. red rubin at different levels of salts, charcoal, sucrose and potassium iodine. Australian Journal of Crop Science, 11(9), 1137. https://doi.org/10.21475/ajcs.17.11.09.pne624

Silva, M. L. C., Costa, R. C., Santana, A. S., \& Bello Koblitz, M. G. (2010). Phenolic compounds, carotenoids and antioxidant activity in plant products. Semina: Ciências Agrárias, 31(3), 669-682. https://doi.org/ $10.5433 / 1679-0359.2010 v 31 n 3 p 669$ 
Souza, G. M., \& Lüttge, U. (2015). Stability as a phenomenon emergent from plasticity-complexity-diversity in eco-physiology. Netherland, NT: Springer. https://doi.org/10.1007/978-3-319-08807-5_9

Sueth-Santiago, V., Mendes-Silva, G. P., Decoté-Ricardo, D., \& Lima, M. (2015). Curcumin, the golden powder from turmeric: Insights into chemical and biological activities. Química Nova, 38(4), 538-552. https://doi.org/10.5935/0100-4042.20150035

Tank, J. G., \& Thaker, V. S. (2011). Cyclin dependent kinases and their role in regulation of plant cell cycle. Biologia Plantarum, 55(2), 201. https://doi.org/10.1007/s10535-011-0031-9

Thomas, T. D. (2008). The role of activated charcoal in plant tissue culture. Biotechnology Advances, 26(6), 618-631. https://doi.org/10.1016/j.biotechadv.2008.08.003

Trettel, J. R., Gazim, Z. C., Gonçalves, J. E., Stracieri, J., \& Magalhães, H. M. (2018). Effects of copper sulfate $\left(\mathrm{CuSO}_{4}\right)$ elicitation on the chemical constitution of volatile compounds and the in vitro development of Basil. Scientia Horticulturae, 234, 19-26. https://doi.org/10.1016/j.scienta.2018.01.062

Trettel, J. R., Nascimento, A. B., Barbosa, L. N., \& Magalhães H. M. (2017). Volatile essential oil chemical composition of basil (Ocimum basilicum L. "Green") cultivated in a greenhouse and micropropagated on a culture medium containing copper sulfate. In Vitro Cellular \& Developmental Biology-Plant, 53(6), 631-640. https://doi.org/10.1007/s11627-017-9868-8

Trettel, J. R., Nascimento, A. B., Barbosa, L. N., \& Magalhães, H. M. (2018b). In vitro growth of genovese basil in response to different concentrations of salts and interaction of sucrose and activated carbon. Journal of Agricultural Science, 10(9), 1-11. https://doi.org/10.5539/jas.v10n9p142

Victório, C. P., Cruz, I. P., Kuster, M. R., \& Luiz, C. S. L. (2011). Terpinen-4-ol is overproduced in tissue cultures of Alpinia zerumbet (Pers.) Burtt et Smith by induction of methyl jasmonate. Latin American Journal of Pharmacy, 30(9), 1858-61.

White, P. J., \& Broadley, M. R. (2003). Calcium in plants. Annals of Botany, 92(4), 487-511. https://doi.org/ 10.1093/oxfordjournals.aob.a089149

Yruela, I. (2009). Copper in plants: Acquisition, transport and interactions. Functional Plant Biology, 36(5), 409-430. https://doi.org/10.1071/FP08288

Zhang, L., Yang, Z., Chen, F., Su, P., Chen, D., Pan, W., \& Du, Z. (2017). Composition and bioactivity assessment of essential oils of Curcuma longa L. collected in China. Industrial Crops and Products, 109, 60-73. https://doi.org/10.1016/j.indcrop.2017.08.009

Zhao, S., Yang, J., Han, X., Gong, Y., Rao, S., Wu, B., \& Yuan, H. (2017). Effects of nanoparticle-encapsulated curcumin on HIV-gp120-associated neuropathic pain induced by the P2X3 receptor in dorsal root ganglia. Brain Research Bulletin, 135, 53-61. https://doi.org/10.1016/j.brainresbull.2017.09.011

\section{Copyrights}

Copyright for this article is retained by the author(s), with first publication rights granted to the journal.

This is an open-access article distributed under the terms and conditions of the Creative Commons Attribution license (http://creativecommons.org/licenses/by/4.0/). 